\title{
ANTES DO PÓS-HUMANO: INSETOS SOCIAIS, MAMÍFEROS SUPERIORES E A (RE) CONSTRUÇÃO DE FRONTEIRAS ENTRE OS HUMANOS E OS ANIMAIS NA MODERNIDADE
}

\author{
Hugo Ferreira* \\ Europa-Universitat Viadrina
}

\begin{abstract}
Resumo:
O presente artigo discute a (re)construção das fronteiras entre os humanos e os animais ao longo dos séculos XIX e XX. Nos séculos XVII e XVIII, o ser humano era visto como fundamentalmente distinto da natureza através da política, sociedade e trabalho, sendo frequentemente comparado então aos insetos sociais. Com a revolução darwiniana no século XIX e a classificação filogenética dos seres vivos, o ser humano foi "primatizado", e assim a humanidade passaria a ser uma consequência da inteligência gerada pelo alto desenvolvimento do sistema nervoso. Atualmente, quando se quer questionar as fronteiras entre o humano e o animal, viram-se os holofotes para outros seres como chimpanzés e golfinhos. Assim, através de uma revisão bibliográfica, este artigo busca explorar um aparente contraste histórico entre os seres a serem comparados aos humanos - dos insetos sociais aos chamados "mamíferos superiores" - bem como suas implicações políticas e bioéticas.
\end{abstract}

Palavras-chave: natureza-cultura; natureza humana; modernidade; antropologia social; história das ciências

\section{BEFORE THE POST-HUMAN: SOCIAL INSECTS, SUPERIOR MAMMALS AND THE (RE) CONSTRUCTION OF BOUNDARIES BETWEEN HUMANS AND ANIMALS IN MODERNITY}

\begin{abstract}
:
The present article discusses the (re)construction of the boundaries between humans and animals along the nineteenth and the twentieth centuries. In the nineteenth and the twentieth centuries, the human being was viewed as fundamentally distinct from nature due to politics, society and work, and then usually compared to social insects. Along the Darwinian revolution in the nineteenth century and the phylogenetic classification of live beings, the human being was "primatized", and humanity would be a consequence of the intelligence due to the high development of the nervous system. Nowadays, when one wants to question the boundaries between humans and animals, the lights are turned to other beings, such as chimpanzees and dolphins. In this sense, as a bibliographic review, this article aims to explore this historical contrast of comparison standards - from insect societies to "superior mammals" - as well, its political and bioethical consequences.
\end{abstract}

Key words: nature-culture; human nature; modernity; social anthropology; history of sciences

\section{Introdução}

Este artigo começou a ser pensado diante da seguinte constatação: a presença dos insetos sociais (principalmente abelhas e formigas) nos textos de pensadores como Aristóteles, Hobbes, Marx, Bergson, Lévi -Strauss, entre outros. Isto nos conduz à pergunta: por que a menção frequente a esses seres vivos e não outros?
A primeira pista pode ser obtida analisando a forma como os insetos sociais eram mencionados, de um modo geral, comparados aos humanos. Mas afinal, o que essas criaturas pertencentes ao outro lado da árvore da vida animal (segundo a concepção científica mainstream) têm a ver com os humanos? A semelhança, ao que parece, é

\footnotetext{
* Doutorando em Ciências Sociais e da Cultura pela Europa-Universitat Viadrina (Alemanha), Mestre em Saúde Pública e Meio Ambiente (FIOCRUZ), Graduado em Ciências Biológicas pela Universidade Federal do Rio de Janeiro, Graduando em Ciências Sociais pela Universidade Federal do Rio de Janeiro. Seu e-mail é hugo.decf@yahoo.com.br
} 
a formação de complexos grupos sociais organizados, hierarquia e uma marcada divisão social do trabalho. Entretanto, ao menos no que tange às ciências sociais, não se pode dizer impunemente que seus coletivos ou sociedades sejam comparáveis aos humanos.

Atualmente, quando se quer questionar as fronteiras entre os humanos e os animais, viram-se os holofotes para outros seres como golfinhos, chimpanzés e os demais primatas. É com eles que são realizados os desafios em inteligência, e é com as imagens de brincadeiras descontraídas e demonstrações de afeto materno para com os filhotes que o público humano reage com maior efervescência.

Portanto, no contexto de uma discussão pós-humanista sobre as fronteiras entre o humano e o não-humano, humano e máquina, ou dentre outros eixos discursivos, o presente artigo propõe a seguinte reflexão: quais critérios têm sido utilizados para definir humanidade? Como a (re)construção desses critérios (e de humanidade) pode afetar as relações com o mundo? Nesse sentido, através de uma revisão bibliográfica, passando tanto pelas ciências biológicas e humanas, tem-se aqui o objetivo de lançar alguma luz sobre esse contraste - dos insetos sociais aos chamados "mamíferos superiores" - em relação aos seres vivos utilizados como analogias com os humanos. Em outras palavras, busca-se discutir alguns fatores que poderiam estar relacionados a essa diferença em relação ao ponto de comparação entre humanos e animais não-humanos. Além disso, pretende-se problematizar as fronteiras criadas entre os humanos e os demais seres vivos no âmbito das ciências humanas.

Finalmente, para fins metodológicos, é preciso explicitar que a análise aqui realizada se restringe ao mundo euro-americano ou ocidental. Sendo assim, demais perspectivas como aquelas que concernem às "sociedades primitivas" ou ao "oriente" não fazem parte do escopo do artigo.

\section{Dos humanos e dos insetos sociais}

Como se sabe, a filosofia cartesiana - à qual muitos atribuem o princípio da ciência moderna ou mesmo do pensamento moderno - postulava uma diferença fundamental entre humanos e demais seres vivos, isto é, os seres vivos seriam máquinas e os humanos um subgrupo especial, por sua vez dotados de alma e razão (Descartes, 2001). No entanto, de acordo com o historiador Keith Thomas (2010), a ideia de uma distinção fundamental entre humanos e demais seres vivos teria sua origem na Grécia antiga. Thomas (2010) comenta que Aristóteles entendia que apenas os humanos teriam uma alma racional ou intelectual. Em suma, os humanos são então vistos como ontologicamente distintos dos outros seres vivos, dotados daquilo que se poderia chamar de "alma". No entanto, ainda que os humanos sejam considerados fundamentalmente distintos, as analogias com os animais são possíveis, e esse é o ponto inicial do presente texto: a recorrência dos insetos sociais em analogias ou comparações com os seres humanos.

Aparentemente, os insetos sociais tinham um lugar singular no pensamento de Aristóteles. De início, note-se que o filósofo grego compreendia os insetos sociais, junto com os humanos, como os únicos seres vivos políticos - embora os humanos se organizassem politicamente num nível mais elevado (Thomas, 2010). De acordo com Clayton (2008), Aristóteles classificava os animais em gregários e solitários. A categoria "gregários", por sua vez, continha a subcategoria "sociais", a qual incluía os humanos e os insetos sociais: "The social animals are those which have some one common activity; and this is not true of all the gregarious animals. Examples of social animals are man, bees, wasps, ants, cranes." (Clayton, 2008). Todavia, apesar da socialidade desses insetos, em sua obra intitulada Política o filósofo grego explicita as diferenças fundamentais em relação aos humanos: "Por esto consta ser el hombre animal político o civil muy más de veras que las abejas, ni que ningún otro animal que va junto en manadas; porque, como ya está dicho, la Naturaleza ninguna cosa hace innecesaria, $y$, entre todos los animales, sólo el hombre tiene uso de razón y de lenguaje" (Aristóteles, Política 1, 1252a15 1252b16). Dessa maneira, ainda que as abelhas sejam referenciadas enquanto "inferiores" em relação aos humanos no que tange à razão, linguagem ou complexidade social, vê-se a presença destas enquanto um ponto de aproximação. Vale remarcar que, por "aproximação", entende-se a validade ou condição para o uso de analogia/comparação entre determinadas características 
entre grupos. Na obra História dos Animais (1991), Aristóteles parece descrever as abelhas com certa admiração, como pode ser interpretado em frases como "entre as abelhas, o modo de actividade e de vida é um processo altamente complexo."; “As abelhas não fogem de qualquer outro animal a não ser dos da sua espécie"; “[...] Cá fora não se agridem umas às outras nem a qualquer outro animal, mas perto da colmeia liquidam qualquer intruso que consigam dominar."; "as abelhas mortas são trazidas pelas companheiras para fora da colmeia. Trata-se, de resto, do animal mais limpo que existe" (Aristóteles 623b-626a).

Em outro contexto histórico, no livro O Homem e o Mundo Natural, o historiador Keith Thomas (2010) analisa as concepções sobre os seres vivos na Inglaterra do período de 1500-1800. Na obra, o autor busca mostrar como era a visão do mundo natural naquilo que seria o berço da modernidade. Ao analisar o modo como os animais eram entendidos na Inglaterra dos séculos XVI, XVII e XVIII, Thomas aponta que a distância entre os humanos e os animais era absoluta, intransponível (Thomas, 2010). No entanto, o autor comenta que no período Stuart as comparações entre as colmeias e as sociedades humanas eram muito populares e isso se estendeu durante o século XVIII (Thomas, 2010). Faziase um elogio deliberado ao trabalho árduo, à organização política e a hierarquia monárquica (Thomas, 2010). Por exemplo, de acordo com Costa (2002), Hobbes chamava a atenção para esses seres que apesar da ausência de razão e linguagem, guiados pelos apetites particulares e sob a tutela de uma monarquia, conseguiam viver tão harmoniosamente. Para ele, a diferença era que a política dos insetos sociais era natural, ao passo que a política dos humanos era artificial - e daí sua característica desarmônica e conflituosa (Costa, 2002). Por serem dotados de razão, os humanos seriam guiados pela competição por dignidade e honra, pela inveja, o que em geral os levaria à guerra. Nas palavras de Hobbes:

É certo que há algumas criaturas vivas, como as abelhas e as formigas, que vivem sociavelmente umas com as outras (e por isso são contadas por Aristóteles entre as criaturas políticas), sem outra direção senão seus juízos e apetites particulares, nem linguagem através da qual possam indicar umas às outras o que consideram adequado para o benefício comum [...] o acordo vigente entre essas criaturas é natural, ao passo que o dos homens surge apenas através de um pacto, isto é, artificialmente. Portanto não é de admirar que seja necessária alguma coisa mais, além de um pacto, para tornar constante e duradouro seu acordo: ou seja, um poder comum que os mantenha em respeito, e que dirija suas ações no sentido do benefício comum (Hobbes, 2000: 146-147).

Portanto, Hobbes reconhece as sociedades de insetos enquanto sociedades propriamente ditas, mas estas seriam restritas ao plano da natureza. As sociedades de insetos seriam regidas por um acordo natural, imposto pela marcada hierarquia. Não haveria ali qualquer juízo ou pacto, sendo estes exclusivos das sociedades humanas, ou de outro modo, da política propriamente dita. Pode-se citar também a famosa Fábula das abelhas de Bernard de Mandeville (1994), publicada originalmente em 1723. A fábula trata de uma colmeia povoada pelo vício e egoísmo, mas que ainda assim funcionava de maneira harmônica. Passando por uma mudança em que a virtude e a ética se tornaram generalizadas, instalou-se uma falta de estímulos para o trabalho árduo, o que rapidamente levou a colmeia ao colapso. Assim, essa fábula visava ilustrar que o egoísmo e o vício dos indivíduos poderiam levar o coletivo para um estado harmônico.

Outra interessante menção às abelhas pode ser vista no volume I d'O Capital, de Karl Marx, datado de 1867, em que se observa a seguinte comparação entre "povos primitivos" e as abelhas:

A cooperação no processo de trabalho, como
a encontramos nas origens culturais da hu-
manidade, predominantemente nos povos ca-
çadores ou eventualmente na agricultura da
comunidade indiana, fundamenta-se, por um
lado, na propriedade comum das condições de
produção e, por outro, na circunstância de que
o indivíduo isolado desligou-se tão pouco do
cordão umbilical da tribo ou da comunidade
como a abelha individual da colmeia (Marx,
1996: 450).

Vê-se, aqui, que tanto as comunidades indianas quanto as colmeias são exemplos utilizados para se con- 
trapor à cooperação nas sociedades capitalistas. Vale lembrar que, para Marx, os humanos se distinguem fundamentalmente através do trabalho:

Uma aranha executa operações semelhantes às do tecelão, e a abelha envergonha mais de um arquiteto humano com a construção dos favos de suas colmeias. Mas o que distingue, de antemão, o pior arquiteto da melhor abelha é que ele construiu o favo em sua cabeça, antes de construí-lo em cera. No fim do processo de trabalho obtém-se um resultado que já no início deste existiu na imaginação do trabalhador, e portanto idealmente (Marx, 1996: 298).

Assim, embora reconheça nos animais a maestria de uma habilidade, Marx argumenta que não é possível igualar estes aspectos ao trabalho exclusivo à dimensão humana, por se caracterizar pelo planejamento, design. Os animais, ao contrário, agiriam guiados pelo instinto (a discussão sobre "instinto" será feita mais a frente). Da mesma forma, diz Marx em $A$ idelogia alemã (2007), a socialidade observada nos animais, tal como observada em abelhas e formigas, também está associada ao instinto, sendo uma "mera consciência gregária", em que a diferença em relação aos humanos reside apenas no fato de que nestes a "consciência toma o lugar do instinto" (Marx, 2007: 35).

Segundo o filósofo Jean-Marc Drouin em seu artigo "Ants and bees. Between the French and the Darwinnian Revolution" (2005), na França do final do século XVIII o mundo dos insetos sociais era visto com fascínio, sobretudo devido à organização política liderada por uma monarquia. Curiosamente, após a revolução francesa, essa visão foi duramente criticada, gerando debates em que se argumentava que na verdade as sociedades de insetos eram repúblicas. De qualquer modo, as sociedades de insetos eram vistas como "miniaturas" das sociedades humanas e, não por acaso, suas descrições eram feitas em termos de "sociedade", "operárias", "rainhas", "soldados", "escravizadores", "colônias" (Drouin, 2005). Assim, as sociedades de insetos funcionariam de maneira semelhante às sociedades humanas.

Nesse sentido, vale comparar a perspectiva hobbesiana com a visão predominante no século XIX. Para Hobbes, ainda que os insetos sociais possuam orga- nização social complexa, a política enquanto fruto da razão e da linguagem faz parte apenas da dimensão humana. Ao contrário, na linha da história natural do século XIX, a política era parte da história evolutiva, e assim, a noção de "miniatura" comentada por Drouin (2005) aponta para leis gerais que governariam tanto as sociedades de insetos quanto as sociedades humanas. Todavia, para compreender como sociedades de insetos poderiam servir como modelo para as sociedades humanas, faz-se necessário apresentar os fundamentos que situam os humanos no mesmo nível dos demais animais na modernidade.

\section{Humanidade e animalidade, da alma ao sistema nervoso}

A ideia de um homem universal tal como defendida pelo iluminismo encontrava oponentes desde o século XVIII. Joseph de Maistre era um reconhecido crítico às doutrinas iluministas na França pós-revolucionária, e em relação à noção de um homem universal, o autor escreveu em 1795: "Já vi na minha vida Franceses, Italianos, Russos etc.; sei até, graças a Montesquieu, que é possível ser Persa: mas quanto ao homem, declaro nunca tê-lo encontrado na minha vida" (apud de Saes, 2011, p.13).

O que o trecho acima revela é que os humanos se definiam principalmente por suas características históricas, por sua humanidade (em oposição à animalidade). Por exemplo, escreve Tim Ingold que o famoso naturalista do século XVIII, Lineu, atribuía a humanidade à condição humana, ou seja, ao saber se reconhecer enquanto humano (Ingold, 1995). Ao longo do século XIX e com o desenvolvimento das ciências naturais, a noção de uma condição humana foi substituída pela ideia de uma espécie humana. Um caso comentado por Ingold (1995) pode facilitar a compreensão desse ponto. Segundo os relatos de alguns viajantes do século XVII e XVIII, haveria nas ilhas do pacífico habitantes semelhantes a seres humanos com caudas, parecidos com macacos, e que andavam sobre duas pernas e conheciam a arte da navegação. Lineu os classificou como macacos. Esses habitantes seriam atualmente classificados como "orangotangos". No entanto, James Burnett - 
também conhecido como Lord Monboddo - afirmou que estes eram humanos, interpretando a questão de um modo distinto:

Eles têm exatamente a forma humana; andam eretos, não de quatro como os selvagens encontrados na Europa; fazem armas com pedaços de madeira; vivem em sociedade; constroem cabanas com galhos de árvores; e roubam moças negras, que tornam suas escravas tanto para o trabalho quanto para o prazer. [...] Mas, se os aspectos acima mencionados levam a crer que eles pertencem a nossa espécie, e embora eles tenham feito grandes progressos nas astúcias da vida, não conseguiram desenvolver a linguagem (apud Ingold, 1995: 6).

Segundo Foucault (1999, p.422), é somente a partir do naturalista Georges Cuvier que se estabeleceram as condições de possibilidade de uma "biologia", em que os humanos deixariam de ser ontologicamente distintos dos outros seres vivos. Embora Cuvier seja associado ao "fixismo", Foucault (1999) argumenta que é com base em suas ideias que os seres vivos são agrupados entre si e classificados de acordo com seus princípios vitais. Portanto, a diferença entre os humanos e os demais animais seria de grau; ou seja, haveria uma continuidade entre os mesmos.

Todavia, é com as teorias evolucionistas e principalmente com a teoria da seleção natural de Darwin que os seres humanos seriam considerados enquanto parte de um ramo da história evolutiva do reino animal. Sobretudo com a publicação d'A Origem das Espécies [1859] de Charles Darwin, a visão que se tinha do mundo da vida sofreu grande transformação. Segundo a teoria da evolução pela seleção natural, as espécies atuais seriam aparentadas entre si, fruto da competição e das modificações herdadas ao longo do tempo. Estava implícita a inclusão dos humanos na árvore da vida, em que Darwin colocava de vez os humanos como mais uma espécie. Logo, levando essa teoria a sério, cria-se uma noção de humanos enquanto animais e como parte da história natural, sendo então aparentados entre si, ou seja, possuiriam um ancestral comum exclusivo. Em outras palavras, não mais um "Homem Universal" associado às luzes, mas um ser humano em termos de sua animalidade ou parentalidade em comum, ou enquanto membro da espécie humana. Nesse sentido, buscou-se então uma classificação dos seres vivos baseada na "história evolutiva" e não mais em critérios ditos arbitrários como utilidade ou domesticação. Assim, passou-se a analisar ossos, crânios, embriogênese, número e distribuição de pelos, penas, escamas, antenas, asas. A vida teria começado em suas formas unicelulares; surgiram os primeiros protozoários, fungos, vegetais; no ramo dos animais, os humanos foram incluídos entre os vertebrados, fazendo parte do grupo taxonômico dos primatas, sendo os chimpanzés e orangotangos os seus parentes mais próximos.

Seguindo a linha de Ingold (1995), a partir do século XIX a humanidade passou a ser circunstanciada pela animalidade. A classificação enquanto história evolutiva é rastreada por meio da hereditariedade, da transmissão de substâncias através dos corpos enquanto estruturas físico-biológicas. Por exemplo, nas reconstruções filogenéticas de outras espécies, ao comparar fósseis com indivíduos atuais, o que se traça é uma semelhança morfológica e corporal, ignorando quaisquer atributos comportamentais - afinal, a hereditariedade se dá em transmissão de substâncias e não de comportamentos. Os aspectos culturais seriam apenas uma especificidade dos humanos, permitida através do desenvolvimento de sistemas nervosos mais complexos (Ingold, 1995). Em outros termos, os humanos continuariam sendo diferentes dos demais animais devido às suas capacidades de abstração, uso e produção de instrumentos ou ferramentas, linguagem; mas, o que antes era uma distinção qualitativa (alma ou cultura) agora é uma distinção quantitativa, fruto do desenvolvimento do sistema nervoso (Ingold, 1995).

Entretanto, as ideias de Darwin apresentadas em A Origem das Espécies desencadearam controvérsias científicas na época. Isso pode ser ilustrado pelo famoso debate entre o bispo Samuel Wilberforce - autoridade cristã de grande retórica à época - e o naturalista Thomas Henry Huxley - conhecido como "buldogue de Darwin" por ser o defensor público da teoria da seleção natural. O debate foi parte de uma conferência em Oxford, em 1860. Um sinal de resistência à teoria da seleção natural e da descendência do ser humano pode 
ser ilustrado no argumento do bispo Wilberforce. Segundo uma mídia local que reportou a conferência, o bispo teria defendido em linhas gerais que:

[...] Darwinian theory, when tried by the principles of inductive science, broke down. The facts brought forward did not warrant the theory [...] the line between man and the lower animals was distinct; there was no tendency on the part of the lower animals to become the self-conscious intelligent being, man; or in man to degenerate and lose the high characteristics of mind and intelligence [...] Mr. Darwin's conclusions were an hypothesis, raised most unphilosophically to the dignity of a causal theory (apud Jensen, 1988, p.166).

Segundo os relatos sobre este debate, Huxley levava vantagem, e a certa altura o bispo pergunta se o naturalista seria descendente de um macaco por parte de mãe ou de pai. Huxley cochicha ao homem ao lado "God hath delivered him into mine hands", e então levanta e responde que preferiria ser descendente de um macaco a ser um bispo que usa sua influência para distorcer a verdade:

\begin{abstract}
A man has no reason to be ashamed of having an ape for his grandfather. If there were an ancestor whom I should feel shame in recalling, it would rather be a man [...], a man of restless and versatile intellect, who, not content with an equivocal success in his own sphere of activity, plunges into scientific questions with which he has no real acquaintance, only to obscure them by an aimless rhetoric, and distract the attention of his hearers from the real point at issue by eloquent digressions and skilled appeals to religious prejudice (apud Jensen, 1988, p.168).
\end{abstract}

Ao fim e ao cabo a tese darwinista prevaleceu, e a proximidade entre humanos e demais primatas se estabeleceu. Como exemplo contemporâneo desta aproximação entre humanos e outros primatas, pode-se perguntar por que se utiliza a ideia de "macaco" como xingamento ou racismo? Parece o caso de uma construção que remonta aos estudos da antropologia biológica do século XIX, onde os negros eram situados como intermediários entre brancos e macacos. Mas o ponto crucial é o que o "macaco" é justamente aquele que está imediatamente inferior na escala dos seres vivos, ou seja, numa zona fronteiriça.

Para além de mera curiosidade, o que se quer mostrar com esse caso é que a aproximação entre os humanos e os macacos não era trivial ou difundida, mas foi construída por uma nova forma de classificação (evolutiva, filogenética) dos seres vivos. Antes as analogias se davam em relação aos insetos sociais em razão de uma aproximação no que concerne à organização social; a partir do fim do século XIX e no XX, os humanos se aproximariam dos animais (em maior ou menor grau) através da história evolutiva. A noção de natureza humana de filósofos como Aristóteles e Hobbes estava associada a uma "essência humana", diferente dessa nova ideia de natureza enquanto biologia, a qual "primatizou" os seres humanos com base em certos caracteres morfológicos e fisiológicos.

\section{Disputando o lugar dos humanos}

Em seu livro Debugging the link between social theory and social insects (2008), a socióloga estadounidense Diane Rodgers ilustra com detalhes as controvérsias científicas e as analogias/comparações entre sociedades de insetos e sociedades humanas. $\mathrm{O}$ argumento central da obra é que a sociologia e a entomologia se influenciaram mutuamente, sobretudo durante o século XIX até meados do século $\mathrm{XX}$, sendo as analogias entre sociedades de humanos e de insetos frequentes durante esse período (Rodgers, 2008). Dentro da trilha "naturalizante" e combinada com o evolucionismo do século XIX, as sociedades de insetos eram utilizadas como instrumento de legitimação de hierarquias, divisão do trabalho, colonialismo (Rodgers, 2008). É somente a partir do século XX que a sociologia realizaria uma ruptura mais profunda com as ciências naturais. E, curiosamente, a partir da segunda metade do século XX e no início do século XXI, as comparações com as sociedades de insetos se tornam mais raras e os humanos passam a ser comparados principalmente com os demais primatas (Rodgers, 2008).

No entanto, se por um lado os humanos foram "primatizados" ao longo do século XIX e XX, por outro 
mantiveram sua especificidade enquanto superiores, inteligentes e sociais. De relance, parece que é esta a base da separação entre uma visão "biologizante" dos humanos, que funcionaria seguindo as mesmas leis naturais que operam nos animais, em oposição àquela "sociologizante", a qual daria ênfase às peculiaridades humanas. Com efeito, a disputa sobre o ser humano enquanto objeto de estudo pode ser ilustrada através de outro texto de Rodgers (2012). No artigo, a autora aborda um debate sobre o uso de insetos sociais como modelos para as sociedades humanas, na esteira da consolidação da psicologia social ainda no início do século XX. O debate é representado pela polarização entre o psicólogo James Mark Baldwin (1861 - 1934) e sociólogo Charles Abram Ellwood (1873 - 1946). Para Rodgers, os dois autores, reconhecidos internacionalmente, simbolizavam claramente os lados opostos do início da psicologia social.

Segundo Rodgers (2012), Baldwin defendia que o desenvolvimento dos instintos era máximo nos insetos sociais, ao passo que nos humanos este se limitava às habilidades mais essenciais (inatas); e assim, o desenvolvimento da criança se fundaria sobretudo através da aprendizagem, da inteligência. Logo, os instintos presentes nos insetos sociais seriam insuficientes para explicar os fenômenos sociais humanos. $\mathrm{Na}$ direção contrária, Ellwood questionava essa distinção e argumentava que Baldwin criava um abismo entre os fenômenos sociais, e defendia que os insetos sociais poderiam servir de modelo para a compreensão de sociedades humanas. Porém, a partir dos anos 1920, a noção de instinto foi sendo abandonada pela sociologia e pela psicologia social, e o próprio Ellwood passou a ser um defensor da especificidade dos fenômenos sociais humanos. Ellwood passou a defender que, embora os insetos sociais apresentassem fenômenos sociais, isso seria gerado por fatores biológicos e geográficos, e não realmente sociais. É somente nas sociedades humanas que se vê cultura. Esse debate reflete uma clivagem entre campos científicos, na qual a ideia de cultura passou a ser dominante na sociologia e na psicologia social (em oposição às explicações em termos de "instinto").

Dessa maneira, se no início do século XX a cultura passou a ser cada vez mais explicada em razão da evolução do sistema nervoso ou simplesmente da inteligência, e as sociedades de insetos passaram a ser um problema a ser resolvido uma vez que estes constituiriam um grupo taxonômico pertencente a outro ramo da árvore filogenética do reino animal. Assim, como explicar a socialidade dos insetos sociais em termos evolutivos? Ao que parece, a noção de "instinto" seria a solução mais simples (assim como Hobbes já tinha escrito sobre os "seres sem juízos" e Marx sobre a "mera consciência gregária”). Nesse âmbito, uma argumentação sofisticada pode ser encontrada no livro Creative evolution $(1907 ; 1922)$ do filósofo Henri Bergson. No livro, Bergson (1922) defende que os dois principais ramos do reino animal (deuterostomados e protostomados Nota 1) são dotados de impulsos vitais distintos. Os deuterostomados seriam caracterizados pelo impulso da inteligência, o qual permite a aferição e abstração, permitindo a fabricação e uso de instrumentos. Assim, os humanos seriam o auge da perfeição da inteligência; logo abaixo, viriam os macacos e elefantes já que sabem utilizar ocasionalmente determinados instrumentos; a seguir aqueles que sabem reconhecer um objeto, por exemplo, a raposa, que tem a capacidade de reconhecer armadilhas. Ao contrário, os protostomados seriam caracterizados pelo impulso do instinto, que seria a faculdade de utilizar instrumentos já organizados, isto é, os apêndices do próprio corpo. Nesse grupo, o auge da perfeição do instinto reside no grupo dos himenópteros (Nota 2), visto sua capacidade de trabalho e organização. Esse elogio aos insetos sociais pode ser percebido no seguinte trecho: "Such is the human species, which represents the culminating point of the evolution of the vertebrates. But such also are, in the series of the articulate, the insects and in particular certain Hymenoptera. It has been said of the ants that, as man is lord of the soil, they are lords of the subsoil" (Bergson, 1922: 141).

Saliente-se que Bergson não atribui exclusividade de instinto para uns e inteligência para outros. $\mathrm{O}$ que ele propõe é uma diferença na origem e proporção em que essas qualidades se manifestam. Assim, os humanos teriam a máxima inteligência até então, sendo que macacos e elefantes, que pertencem também ao grupo dos vertebrados, apresentam a inteligência em proporções menores. Fica evidente que para o autor a 
proximidade dos humanos junto aos demais vertebrados é um dado. No entanto, o mais interessante é que os insetos sociais são elevados ao posto de máxima evolução em seu próprio grupo. Bergson escreve sobre estes seres: "We get this impression when we compare the societies of bees and ants, for instance, with human societies. The former are admirably ordered and united, but stereotyped; the latter are open to every sort of progress, but divided [...]" (Bergson, 1922: 105-106). Dessa maneira, Bergson entende as sociedades de insetos enquanto sociedades propriamente ditas, e aponta que estas são baseadas no máximo ordenamento e estabilidade (guiadas pelo instinto), ao passo que as sociedades humanas são marcadas pela instabilidade e pela mudança (guiadas pelo intelecto).

Em última análise, o que se vê é a acomodação entre a explicação da socialidade humana através da inteligência e um reconhecimento da complexa organização social entre os insetos sociais, estando os últimos dotados dos instintos mais perfeitos ou precisos. Seria isso talvez um resquício histórico de comparação/admiração com os insetos sociais?

Entretanto, como já mencionado nesta seção, as explicações dos fenômenos sociais através dos instintos foram cada vez mais rejeitadas pelas ciências sociais. Todavia, os instintos continuaram a ser estudados principalmente pelos biólogos e psicólogos behavioristas. Como exemplo, pode-se citar o artigo de William Wheeler (1923), estudioso do comportamento e das relações de parasitismo em formigas. Ao longo do texto, o autor faz frequentes comparações com as sociedades humanas, e diz que assim como as formigas, possuímos nossos parasitas improdutivos, tais como "criminosos", "burocratas" e "prostitutas".

E por fim, como se sabe, a busca pela explicação das sociedades humanas nos fenômenos sociais animais se faz presente, principalmente, no escopo da sociobiologia. Para citar apenas três autores de maior renome, destaca-se aqui: 1) Desmond Morris e o livro O macaco $n u$ (1968), em que os humanos são entendidos como um grupo peculiar de primatas, e as relações sociais como aparatos evolutivos; 2) Richard Dawkins, que em seu famoso livro O gene egoísta (2001) defende a tese sobre os seres vivos enquanto máquinas replicadoras, um mero aparato utilizado pelos genes, sendo toda a socialidade uma evolução inconsciente gerada pela seleção natural entre os genes. Curiosamente, no texto citado Dawkins dedica dezenas de páginas ao "problema" do altruísmo entre as abelhas operárias, pois, uma vez que elas não se reproduzem, estas representariam evolutivamente um mistério a ser solucionado. A explicação do autor é que a seleção natural opera em nível genético, e portanto, o altruísmo é apenas uma aparência, sendo na verdade reflexo do egoísmo em nível genético; 3 ) e por último Edward O.Wilson (1999), principal nome no que se refere à sociobiologia. Como uma ilustração dos princípios que norteiam essas análises, vale observar o trecho abaixo e o modo como as relações sociais dentre humanos e outros animais são comparadas:

[...] All mammals, including humans, form societies based on a conjunction of selfish interests. Unlike the worker castes of ants and other social insects, they resist committing their bodies and services to the common good. Rather, they devote their energies to their own welfare and that of close kin. For mammals, social life is a contrivance to enhance personal survival and reproductive success. As a consequence, societies of nonhuman mammalian species are far less organized than the insect societies. They depend on a combination of dominance hierarchies, rapidly shifting alliances, and blood ties. Human beings have loosened this constraint and improved social organization by extending kinship like ties to others through long-term contracts (Wilson, 1999: 186).

Em primeiro lugar, vale notar que para os sociobiólogos as socialidades nos insetos e nos mamíferos são comparadas sem grandes restrições, sugerindo que estas são da mesma natureza. Outro ponto interessante é que nos insetos sociais a socialidade é uma completa devoção ao bem comum, o que não ocorreria nos humanos, e por isso a organização social complexa entre estes seria uma compensação às "relativamente fracas" relações de parentesco (elevadas ao máximo nos insetos sociais). 


\section{Dos insetos sociais aos mamíferos superiores nas ciências sociais}

Embora o humano enquanto objeto biológico ou sociológico ainda seja disputado, o fato é que os humanos foram "primatizados" - tanto para um biólogo quanto para um filósofo. Assim, esta seção visa fornecer uma breve ilustração desse fenômeno no campo das ciências humanas, abordando alguns aspectos em obras dos seguintes autores: Alfred Kroeber, Alfred Radcliffe-Brown e Claude Lévi-Strauss. Essa escolha leva em conta ao menos três critérios: 1) a considerável relevância dos autores; 2) o modo como os mesmos delimitam as fronteiras entre a socialidade humana e a dos demais seres vivos; 3 ) o fato de mencionarem os insetos sociais em seus textos.

O antropólogo Alfred Kroeber, no famoso artigo O superorgânico, de 1917, discute explicitamente o "problema" dos insetos sociais. Em termos gerais, o texto pode ser lido como uma empreitada no sentido de isolar as ciências humanas das ciências naturais. Mas é particularmente curiosa a dedicação do autor em estabelecer uma distinção entre as sociedades humanas e as sociedades de insetos. Em suas palavras: "As formigas e as térmites possuem sociedades, mas não têm uma cultura. Só o homem tem ambas, sempre necessariamente associadas, embora conceptualmente diferenciáveis" (Kroeber, 1993: 40). E ainda mais detalhadamente:

A divergência entre forças sociais e orgânicas talvez não seja plenamente entendida enquanto não aprofundarmos a mentalidade dos chamados insectos sociáveis, as abelhas e as formigas. A formiga é social na medida em que associa; mas está tão longe de ser social no sentido de possuir civilização, de ser influenciada por forças não orgânicas, que mais valia ser conhecida por animal anti-social. [...] A sociedade das formigas é tão pouco parecida com uma verdadeira sociedade, no sentido humano, como uma caricatura com um retrato (Kroeber, 1993: 51).

Em outro diapasão, o antropólogo britânico Alfred Radcliffe-Brown (1940) defendia que outros animais seriam tão sociais quanto os humanos - caso a socialidade seja entendida enquanto interação entre agregados de indivíduos. Note-se o trecho abaixo:
For a preliminary definition it seems sufficiently clear that what we have to deal with are relations of association between individual organisms. In a hive of bees there are the relations of association of the queen, the workers and the drones. There is the association of animals in a herd, of a mother-cat and her kittens. I do not suppose that anyone will call them cultural phenomena. In social anthropology, as I define it, what we have to investigate are the forms of association to be found amongst human beings (Radcliffe-Brown, 1940: 2).

Assim, Radcliffe-Brown argumenta que tanto uma colmeia de abelhas quanto uma família de gatos seriam sociais na medida em que são associações entre organismos individuais. Como organismos individuais, estes seriam seres biológicos, e devem ser estudados pelas ciências naturais. Já os seres humanos, sendo pessoas, caberia aos antropólogos sociais o respectivo estudo. Escreve o autor: "Social phenomena constitute a distinct class of natural phenomena" (Radcliffe-Brown, 1940: 3). Em suma, os animais seriam sociais, mas suas estruturas sociais seriam de uma natureza distinta da humana.

No que tange à socialidade dos insetos sociais, pode-se notar o contraste entre os escritos de Kroeber e Radcliffe-Brown com aquele apresentado por Lévi-Strauss nas primeiras páginas do capítulo I d'As Estruturas Elementares do Parentesco (1982), originalmente publicado em 1948. O autor inicia o famoso texto questionando como a cultura teria surgido a partir da natureza. E em relação às sociedades de insetos, comenta que "A passagem - se existe - não poderia pois ser procurada na etapa das supostas sociedades animais, tais como são encontradas entre alguns insetos". Está claro aqui que, para Lévi-Strauss, "sociedades de insetos" já é uma contradição em termos, uma vez que não se pode atribuir o status de "sociedade" a estes coletivos. Mais ainda, na mesma página Lévi-Strauss argumenta: "Não há nessas estruturas coletivas nenhum lugar mesmo para um esboço do que se pudesse chamar o modelo cultural universal, isto é, linguagem, instrumentos, instituições sociais e sistema de valores estéticos, morais ou religiosos" (Lévi-Strauss, 1982: 44). Ora, vê-se aqui uma desqualificação profunda no estatuto de sociedade no que tange aos insetos, uma ruptura mesmo com as concepções dos séculos XVIII e XIX aqui comentadas. 
Hugo Ferreira, Antes do Pós-humano: insetos sociais, mamíferos superiores e a (re)construção de fronteiras...

Os insetos sociais teriam uma mera "estrutura coletiva”. E com efeito, ao fim deste mesmo parágrafo Lévi -Strauss argumenta: "É à outra extremidade da escala animal que devemos nos dirigir, se quisermos descobrir o esboço desses comportamentos humanos. Será com relação aos mamíferos superiores, mais especialmente os macacos antropóides" (Lévi-Strauss, 1982: 44).

Lévi-Strauss comenta que, embora de forma muito rudimentar, alguns atributos humanos podem ser observados em alguns macacos. $\mathrm{O}$ uso de instrumentos e da linguagem, a deficiência nas instituições e nos sistemas de valores representa uma distância enorme, uma vez que "o comportamento instintivo perde nitidez e a precisão que encontramos na maioria dos mamíferos, mas a diferença é puramente negativa e o domínio abandonado pela natureza permanece sendo um território não ocupado" (Lévi-Strauss, 1982: 46). Em outras palavras, os demais primatas já não são seres regidos completamente pelo instinto, mas tampouco alcançaram níveis de razão próximos aos humanos. Para o autor, indubitavelmente reside um fator diferenciador entre humanos e outros animais.

Assim, é possível perceber que esta problemática da socialidade dos insetos sociais está longe de ser encerrada, e mais do que isso, é atualizada à medida que novos estudos no campo da biologia e da sociologia se desenvolvem e interpenetram. Mas, ao que parece, os autores colocam os humanos de modo inquestionável como aqueles seres dotados de "alguma coisa além", seja a razão/intelecto, estruturas sociais, linguagem ou simbolismo (ou combinações destes). Mas o que há de diferente na compreensão destes autores em relação aos coletivos não humanos?

Em Kroeber, as sociedades de insetos e de humanos são de natureza completamente distinta, pois os primeiros pertencem exclusivamente ao mundo orgânico - as formigas e térmites seriam melhor conhecidos como "anti-sociais". As sociedades humanas seriam algo supranatural, superorgânico, e que transcenderia os próprios organismos individuais.

Vale abrir aqui um parêntese e comparar o texto de Kroeber com o argumento de Geertz em Interpretação das culturas (1973; 1989). Para Geertz, os hominídeos atuais são fruto não exclusivamente de um desenvol- vimento anatômico que tenha possibilitado a cultura, mas de uma longa sobreposição temporal entre aspectos culturais rudimentares e os hominídeos, o que, por retroalimentação positiva, gerou uma mudança tanto da cultura quanto da biologia dos humanos. Ao analisar os animais como um todo, vê-se uma relação entre crescimento do sistema nervoso ou número de neurônios e de faculdades como locomoção, memória e demais estímulos sensoriais. $\mathrm{O}$ grande passo foi uma rearticulação do sistema nervoso central nos mamíferos. No entanto, em relação ao número de neurônios, não haveria grande diferença entre os primatas inferiores e os humanos. Geertz justifica então essa diferença intelectual pela presença de cultura. Um dos argumentos que justifica essa análise está numa dada passagem em que Geertz comenta que os primatas infra-hominídeos não possuem cultura (enquanto sistema de símbolos e significados), mas, por outro lado, estes apresentariam certa organização social, aprendizado imitativo e transmitem tradições coletivas não biologicamente de geração em geração. Logo, essa seria a prova de que é possível ter alguma organização social sem apresentar uma "cultura verdadeira", e que esse seria o caso dos humanos - como se um "impulso social" tivesse levado ao desenvolvimento do sistema nervoso central, e finalmente, a uma "cultura verdadeira" (Geertz, 1989). Porém, é interessante notar que Kroeber deixa explícito que as formigas e térmites têm sociedades, mas não cultura. Da mesma maneira, Geertz comenta que outros primatas têm sociedades, mas apenas os humanos têm cultura. Poder-se-ia dizer, as comparações de Kroeber e Geertz apontam para aquilo que vem a ser o principal argumento desta seção: enquanto no início do século XX Kroeber se esforçava em desqualificar culturalmente os insetos sociais, Geertz, nos anos 1970, fazia o mesmo em relação aos demais primatas.

Em Lévi-Strauss, as sociedades de insetos não são comparáveis às sociedades humanas, e caso seja necessário distinguir sociedades humanas e não humanas, é sobre os primatas que se deve debruçar - ainda que estes não apresentem mais do que alguns rudimentos daquilo que se possa chamar de "social".

Portanto, com base na discussão desta seção, ilustra-se por meio da antropologia social um movimento 
geral de primatização do ser humano, o que de certo modo alterou o objeto de comparação. Se Kroeber se esforçava em delimitar a fronteira entre insetos sociais e humanos, Geertz já não precisava se preocupar tanto com o assunto.

\section{Problematizando as fronteiras}

Enquanto biólogo, ao iniciar meus estudos em ciências sociais, chocava-me o modo como alunos e professores postulavam um abismo entre humanos e animais. De certa maneira, era o mesmo princípio etnocêntrico que se aplicava aos "primitivos", mas nesse caso um antropocentrismo aplicado aos demais seres vivos. Desde o início do curso de ciências sociais, os alunos aprendem a criticar comparações entre humanos e animais e seus derivados "reducionismos", com base na premissa de que os humanos têm "cultura" e outras características que os distinguem fundamentalmente dos demais seres vivos.

Essa questão me pareceu mais clara ao me deparar com livro O Roubo da História, de Jack Goody (2008). $\mathrm{O}$ autor argumenta que a distinção entre Ocidente e Oriente, "nós" e "eles", estava dada a priori para os historiadores; o que a historiografia fez foi buscar as diferenças que explicariam essa distinção. E os historiadores as encontraram: o Ocidente seria o inventor da civilização, do amor, do capitalismo, estabelecendo-se os critérios de distinção. Resumindo grosseiramente a crítica de Goody, os ocidentais, em primeiro lugar, criaram as fronteiras a priori ("nós" e "eles"); atribuíram para si elementos que já eram presentes em outros povos, e supervalorizando certas diferenças, ignoraram as semelhanças.

Nessa trilha, a tese defendida ao longo do texto é que os parâmetros que definem as fronteiras entre humanos e outros seres vivos (sobretudo os animais) passaram por modificações no Ocidente. Proponho que se pense num sistema de subjetividades formado por círculos concêntricos - sendo o centro ocupado pelos humanos (sujeitos) e o círculo mais distante o objeto enquanto tipo ideal. Antes da formulação de uma história natural propriamente dita, os humanos estavam isolados no centro por um abismo; no círculo seguin- te estavam os insetos sociais. A separação se dava por uma "alma", razão, linguagem, e o critério de aproximação era a organização social ou política, hierarquia e a divisão do trabalho. A partir do século XIX e principalmente do século XX, os humanos continuaram no centro defendido pelos mesmos aspectos gerais, mas já não havia um abismo intransponível, e sim, uma história evolutiva em comum, uma semelhança filogenética, biológica e substancial. No círculo seguinte estavam os demais primatas; depois os mamíferos e demais vertebrados; animais; vegetais; fungos, protozoários e bactérias como os objetos por excelência (se distinguindo apenas da matéria inanimada).

Mais do que um exercício intelectual, parece que essa nova economia das subjetividades, de fato, se estruturou em algum grau no senso comum. Exemplo: é possível pensar que uma pessoa tem menor chance de ser repreendida por pisar e esmagar uma barata, formiga ou lacraia do que um rato ou sapo. Descola já comenta que muitos defensores dos animais se preocupam com golfinhos, mas "quanto às medusas ou às tênias, nem mesmo os membros mais militantes dos movimentos de liberação animal parecem conceder-lhes uma dignidade tão consequente quanto a outorgada aos mamíferos e aos pássaros" (Descola, 1998: 24). O que está em jogo - generalizando de forma um pouco grosseira - é que em certa medida o sistema de classificação segundo a história evolutiva se instaurou nas esferas de subjetividade modernas. Complementando o comentário de Descola (1998) sobre o antropocentrismo que resulta nessa assimetria nas defesas dos direitos dos animais, note-se que o uso de animais em laboratórios vai muito além de mamíferos e pássaros, e com efeito, é provável que se utilize mais insetos do que qualquer outro grupo taxonômico animal. E quanto aos vegetais, fungos, protozoários e bactérias? A experiência pessoal do presente autor aponta que, ao fazer essa pergunta para um defensor dos animais ou um vegetariano, a resposta circula em torno da ideia de dor ou sofrimento, que, por sua vez, está relacionada ao sistema nervoso. Vale lembrar, considera-se que apenas os animais sejam dotados de sistema nervoso, ao passo que os demais seres vivos teriam uma mera "sensibilidade". Assim, vegetais sofreriam menos que insetos, que, por sua vez, menos 
que mamíferos. Como foi sugerido anteriormente, parece que a noção de sistema nervoso substituiu a "alma" enquanto condição de subjetividade. Assim, essa subjetividade está distribuída de maneira assimétrica entre os seres vivos, já que alguns possuem sistemas nervosos ditos mais complexos do que outros. Mas infelizmente não há espaço para aprofundar essa discussão.

No entanto, na linha de pensamento de Ingold, é preciso distinguir entre o mundo criado pela ciência e o mundo vivido pelas pessoas. Ainda que a ciência diga quais seres são inteligentes ou não, as pessoas lidam com estes de forma diferenciada. Conforme observa Ingold em A circumpolar's night dream (2000), os animais de estimação são frequentemente considerados, se não pessoas, ao menos "quase pessoas", e às vezes considerados membros da família de seus donos.

Além disso, pode-se também problematizar a fronteira entre os humanos e os animais criada pelos cientistas sociais em geral: até que ponto os animais não possuem uma cultura (racionalidade própria, sistemas de valores), como os primatólogos creem que os primatas possuam, mas que é inacessível para nós (da mesma maneira que a "cultura" dos primitivos era vista como "instinto" pelos ocidentais)? Acrescentaria que a mesma aproximação que permite aos primatólogos ver macacos como sujeitos dotados de cultura e que interagem socialmente entre si e com seres humanos também ocorre entre os humanos e seus respectivos animais domésticos. Invariavelmente os donos reconhecem que seus animais fazem "manha" ou "birra", ficam com ciúmes, tristes, aprendem a se comunicar.

\section{Considerações finais}

Reflexivamente, vale questionar, por que discutir insetos sociais e primatas no imaginário ocidental? Creio que essa hipótese pode contribuir em alguma medida para certas questões bioéticas e políticas atuais. A nossa compreensão do mundo vivo está em constante reformulação, e esse processo, longe de ser algo puramente "científico", invade (cada vez mais) todas as esferas da vida. Afinal, não é o aborto uma discussão em torno de uma subjetividade (do feto) ou não? E curiosamente, é o início da formação do sistema ner- voso que caracteriza consciência e sensibilidade, e assim, o indivíduo já possuiria seus direitos humanos. Ou ainda, as discussões em torno dos direitos dos animais, das células-tronco, do patrimônio genético, clonagem, transgenia e entre outros - questões bioéticas que suscitam a reflexão sobre quem são os sujeitos e quem são os objetos, ou melhor dizendo, "quem são os sujeitos que podem dizer quem são os outros sujeitos, e os objetos e o que fazer com eles"? Em última análise, talvez o presente caso possa re-discutir de que modo pode se dar a negociação das subjetividades e da humanidade.

Por fim, diante de uma virada pós-humanista, ao sugerir que o caráter "humano" de alguns seres é historicamente circunstancial e fruto de um desenvolvimento epistemológico-político nos últimos séculos, vê-se então a fragilidade da noção "humano". Em suma, antes de perguntar sobre os futuros desafios ontológicos, vale questionar: mas afinal, o que são os humanos?

\section{Notas}

1. Na filogenia do reino animal, existe uma bifurcação entre dois grandes grupos: os deuterostomados, representados pelos equinodermos e vertebrados; e os protostomados, representados pelos moluscos, anelídeos e insetos.

2. Grupo taxonômico que abrange as abelhas, formigas e vespas.

\section{Agradecimentos}

Agradeço aqui as revisões e sugestões dos pesquisadores Luiz Felipe Lima da Silveira (UFRJ) e Marco Antônio Gonçalves (UFRJ)).

\section{Referências}

ARISTÓTELES. Política 1, 1252a15 - 1252b16.

ARISTÓTELES. História dos animais, livros XVII-X. Cambridge, MA: Harvard University Press, 1991.

BERGSON, Henri. Creative Evolution. London: MacMillan and Co, Limited, 1922.

CLAYTON, Edward. (2008). Aesop, Aristotle, and animals: The role of fables in human life. Humanitas, v. 21, n. 2, p. 179-200.

COSTA, James. Scale models? (2002). What insect societies teach us about ourselves. Proceedings of the American Philosophical Society, v.146, n.2, p.170-180. 
DAWKINS, Richard. O gene egoísta. Belo Horizonte: Itatiaia, 2001.

DE SAES, Laurent. (2008). Joseph de Maistre e suas Considerações sobre a França Revolucionária. Revista Territórios \& Fronteiras, v. 1, n. 1, p. 6-18.

DESCARTES, René (2001). Discurso do método. São Paulo: Martins Fontes.

DESCOLA, Philippe. (1998). Estrutura ou sentimento: a relação com o animal na Amazônia. Mana, v. 4, n. 1, p. 23-45.

DROUIN, Jean Marc. (2005). Ants and bees. Between the French and the Darwinnian revolution. Ludus Vitalis, v.13, n.24, 3-14.

FOUCAULT, Michel. As Palavras e as coisas: uma arqueologia das ciências humanas. São Paulo, Martins Fontes, 1999.

GEERTZ, Clifford. A Interpretação das culturas. Rio de Janeiro: Editoria Guanabara Koogan, 1989.

GOODY, Jack. O Roubo da história. São Paulo: Editora Contexto, 2008.

HOBBES, Thomas. Leviatã ou matéria, forma e poder de um Estado Eclesiástico e Civil. São Paulo: Nova Cultura, 2000.

INGOLD, Tim. Humanidade e animalidade. (1995). Revista Brasileira de Ciências Sociais, v.28, n.10, p. 39 $-53$.

(2000). The Perception of the environment: essays on livelihood, dwelling and skill. Psychology Press.

JENSEN, J. Vernon. (1988). Return to the WilberforceHuxley Debate. The British Journal for the History of Science, v.21, n.2, p.161-179.

LÉVI-STRAUSS, Claude. As Estruturas elementares do parentesco. 2. Ed. Petrópolis: Editora Vozes., 1982.

KROEBER, Alfred. A Natureza da cultura. Lisboa: Edições 70, LDA, 1993.

MANDEVILLE, Bernard de. A Fábula das Abelhas. (1994). Disponível em: http://www.braudel.org.br/ publicacoes/bp/bp05_pt.pdf. Acesso em 8 jan. 2015.

MARX, Karl. O capital. São Paulo: Editora Nova Cultural, 1996.

2007.

. A Idelogia alemã. São Paulo: Boitempo Editorial,

MORRIS, Desmond. O macaco nu: um estudo do animal humano. Rio de Janeiro: Record, 1968.

RADCLIFFE-BROWN, Alfred Reginald. (1940). On social structure. Journal of the Anthropological Institute of Great Britain and Ireland, p. 1-12.
RODGERS, Diane. (2008). Debugging the link between social theory and social insects. LSU Press.

. (2012). Insects, instincts and boundary work in early social psychology. History of the Human Sciences, v.26, n.68, p. 68-89.

THOMAS, Keith. O Homem e o mundo natural. São Paulo: Companhia das Letras, 2010.

WHELEER, William Morton. (1923). Social life among insects. The Scientific Monthly, v.16, n.1, p.5-33.

WILSON, Edward O. Consilience: The unity of knowledge. New York, Vintage, 1999.

Recebido em: 08/11/2016 Aceito em: 10/03/2017 